\title{
Przyczynek do chronologii królów Izraela i Judy
}

\author{
Paweł M. Mucha \\ Poznań \\ pablomarco@wp.pl (10 https://orcid.org/0000-0001-9926-6623
}

Chronologia królów Izraela i Judy jest jedną z niezwykle istotnych i zarazem skomplikowanych kwestii w Starym Testamencie ${ }^{1}$. Podejmowano różne próby ustalenia dat panowania władców obu tych królestw². Wiele trudności można rozwiązać, uwzględniając, że $\mathrm{e}^{3}$ :

1. Na starożytnym Bliskim Wschodzie stosowano dwie metody podawania lat rządów poszczególnych władców: przeddatację i podatację

1 T. Brzegowy, Chronologia epoki królewskiej w starożytnym Izraelu, „Ruch Biblijny i Liturgiczny” 51 (1998) nr 4, s. 261-270, https://doi.org/10.21906/rbl.697.

2 E. R. Thiele, The Mysterious Numbers of the Hebrew Kings, Grand Rapids 1994; E. R. Thiele, The Chronology of the Kings of Judah and Israel, „Journal of Near Eastern Studies” 3 (1944) nr 3, s. 137-186, https://doi.org/10.1086/370716; V. Pavlovský, E. Vogt, Die Jahre der Könige von Juda und Israel, „Biblica” 45 (1964) nr 3, s. 321-347; W. F. Albright, The Chronology of the Divided Monarchy of Israel, „Bulletin of the American Schools of Oriental Research” 100 (1945), s. 16-22, https://doi. org/10.2307/1355182; A. Jepsen, R. Hanhart, Untersuchungen zur israelitisch-jüdischen Chronologie, Berlin 1964; G. Larsson, The Chronology of the Kings of Israel and Judah as a System, „Zeitschrift für die Alttestamentliche Wissenschaft” 114 (2006) nr 2, s. 224-235, https://doi.org/10.1515/ zatw.2002.012; G. Galil, The Chronology of the Kings of Israel and Judah, Leiden-New York-Köln 1996 (Studies in the History and Culture of the Ancient Near East, 9); W. H. Barnes, Studies in the Chronology of the Divided Monarchy of Israel, Leiden 1991 (Harvard Semitic Monographs, 48), https://doi.org/10.1163/9789004369573; A. Laato, New Viewpoints on the Chronology of the Kings of Judah and Israel, „Zeitschrift für die Alttestamentliche Wissenschaft” 98 (2009) nr 2, s. 210-221, https://doi.org/10.1515/zatw.1986.98.2.210; W. Wifall, The Chronology of the Divided Monarchy of Israel, „Zeitschrift für die Alttestamentliche Wissenschaft” 80 (2009) nr 3, s. 319-337, https://doi. org/10.1515/zatw.1968.80.3.319; M. Christine Tetley, The Reconstructed Chronology of the Divided Kingdom, Winona Lake 2005; J. Hayes, P. Hooker, A New Chronology for the Kings of Israel and Judah and Its Implications for Biblical History and Literature, Eugene 2007.

3 A. Cundall, Chronologia królów, [w:] Przewodnik po Biblii, red. nauk. D. i P. Alexander, konsultacja nauk. pol. wyd. W. Chrostowski, M. Wojciechowski, przekł. i red. T. Mieszkowski, Warszawa 1997, s. 269-271.

4 E. Curtis, The Old Testament Reckoning of Regnal Years, „Journal of Biblical Literature” 14 (1895) nr 1-2, s. 125-130, https://doi.org/10.2307/3268894; J. Miller, Another Look at the Chronology of the Early Divided Monarchy, „Journal of Biblical Literature” 86 (1967) nr 3, s. 276-288, https://doi. org/10.2307/3263008. 
2. Juda i Izrael posiadały różne kalendarze, według których rok zaczynał się w różnym czasie ${ }^{5}$.

3. W wyniku współrządów rządy niektórych władców zazębiały się

4. Niektórzy rywalizujący ze sobą władcy mogli rządzić w tym samym czasie tylko niektórymi obszarami państwa7 ${ }^{7}$.

Mimo to są duże trudności w ustaleniu okresów panowania władców Izraela i Judy ${ }^{8}$. Genealogie królów mogą być jednak wynikiem głębokiej pracy redakcyjnej autora biblijnego. John H. Hull zwraca uwagę, że listy królów izraelskich i judzkich po śmierci Salomona składają się z 19 władców każda ${ }^{9}$ :

5 D. Clines, The Evidence for an Autumnal New Year in Pre-Exilic Israel Reconsidered, „Journal of Biblical Literature" 93 (1974) nr 1, s. 22-40, https://doi.org/10.2307/3263863; E. Auerbach, Der Wechsel des Jahres-Anfangs in Juda im Lichte der Neugefundenen Babylonischen Chronik, „Vetus Testamentum” 9 (1959) nr 2, s. 113-121, https://doi.org/10.1163/156853359X00186; S. Talmon, Divergences in Calendar-Reckoning in Ephraim and Judah, „Vetus Testamentum” 8 (1958) nr 1, s. 48-74, https://doi.org/10.1163/156853358X00042; J. B. Segal, Intercalation and the Hebrew Calendar, „Vetus Testamentum” 7 (1957) nr 1, s. 250-307, https://doi.org/10.1163/156853357X00205; D. Clines, Regnal Year Reckoning in the Last Years of the Kingdom of Judah, „Australian Journal of Biblical Archaeology” 1 (1972) nr 5, s. 9-34; zob. także E. Auerbach, Die Babylonische Datierung im Pentateuch und sas Alter ses Priester-Kodex, „Vetus Testamentum” 2 (1952) nr 1, s. 334-342, https://doi.org/10.1163/156853352X00426.

6 Np. E. Thiele, Coregencies and Overlapping Reigns among the Hebrew Kings, „Journal of Biblical Literature" 93 (1974) nr 2, s. 174-200, https://doi.org/10.2307/3263092; E. Ball, The Co-Regency of David and Solomon (1 Kings I), „Vetus Testamentum” 27 (1977) nr 3, s. 268-279, https://doi. org/10.1163/156853377X00168; zob. także D. B. Redford, The Coregency of Tuthmosis III and Amenophis II, „The Journal of Egyptian Archaeology” 51 (1965) nr 1, s. 107-122, https://doi. org/10.1177/030751336505100111.

7 E. R. Thiele, The Mysterious Numbers of the Hebrew Kings, Grand Rapids 1994, s. 61-65; H. Cook, Pekah, „Vetus Testamentum” 14 (1964) nr 2, s. 121-135, https://doi.org/10.2307/1516376.

8 E. R. Thiele, A Comparison of the Chronological Data of Israel and Judah, „Vetus Testamentum” 4 (1954) nr 1, s. 185-195, https://doi.org/10.1163/156853354X00172; E. Thiele, Pekah to Hezekiah, „Vetus Testamentum” 16 (1966) nr 1, s. 83-107, https://doi.org/10.1163/156853366X00458; A. Green. The Chronology of the Last Days of Judah: Two Apparent Discrepancies, „Journal of Biblical Literature” 101 (1982) nr 1, s. 57-73, https://doi.org/10.2307/3260440; G. Galil, The Babylonian Calendar and the Chronology of the Last Kings of Judah, „Biblica” 72 (1991) nr 3, s. 367-378, https:// doi.org/10.2143/BIB.72.3.3217725; N. Na'aman, Historical and Chronological Notes On the Kingdoms of Israel and Judah in the Eighth Century B.C., ,Vetus Testamentum” 36 (1986) nr 1, s. 71-92, https:// doi.org/10.1163/156853386X00159.

9 J. Hull, King Lists as a Structuring Principle in the Book of Kings, [w:] Partners with God: Theological and Critical Readings of the Bible in Honor of Marvin A. Sweeney, eds. S. L. Birdsong, S. Frolov, t. 2, Claremont 2017, s. 133-146, https://doi.org/10.2307/j.ctvbcd33m.17. 


\begin{tabular}{|c|c|c|c|}
\hline \multicolumn{2}{|c|}{ Lista królów Izraela } & \multicolumn{2}{|c|}{ Lista królów Judy } \\
\hline 1 & Jeroboam I & 1 & Roboam \\
\hline 2 & Nadab & 2 & Abiasz \\
\hline 3 & Basza & 3 & Asa \\
\hline 4 & Ela & 4 & Jozafat \\
\hline 5 & Zimri & 5 & Joram \\
\hline 6 & Omri & 6 & Ochozjasz \\
\hline 7 & Achab & 7 & Joasz \\
\hline 8 & Ochozjasz & 8 & Amazjasz \\
\hline 9 & Joram & 9 & Azariasz \\
\hline 10 & Jehu & 10 & Jotam \\
\hline 11 & Joachaz & 11 & Achaz \\
\hline 12 & Joasz & 12 & Ezechiasz \\
\hline 13 & Jeroboam II & 13 & Manasses \\
\hline 14 & Zachariasz & 14 & Amon \\
\hline 15 & Szallum & 15 & Jozjasz \\
\hline 16 & Menachem & 16 & Joachaz \\
\hline 17 & Pekachiasz & 17 & Jojakim \\
\hline 18 & Pekach & 18 & Jojakin \\
\hline 19 & Ozeasz & 19 & Sedecjasz \\
\hline
\end{tabular}

Razem z królami Zjednoczonego Królestwa-Saulem, Dawidem i Salomonem - dają 41 władców. Taka kompozycja genealogii królów judzkich i izraelskich nie odzwierciedlałaby rzeczywistej liczby władców, lecz byłaby skutkiem wzorowania się redaktora Ksiąg Królewskich na asyryjskich listach królów ${ }^{\mathbf{1 0}}$, które zdradzają pewien schematyzm w liczbie władców, ich kolejności, a nawet długości panowania ${ }^{11}$.

Z tą koncepcją nie można się zgodzić. J. H. Hull nie uwzględnia bowiem na liście królów izraelskich Tibniego, a na liście królów judzkich - Atalii. Pominięcie Tibniego nie budzi żadnych wątpliwości. Według autora Ksiąg Królewskich po śmierci Zimriego lud izraelski podzielił się: „połowa chciała obwołać królem Tibniego, syna Ginata, a połowa była za Omrim” (1 Krl 16, 21).

10 Tamże.

11 J. Høyrup, "Remarkable Numbers” in Old Babylonian Mathematical Texts: A Note on the Psychology of Numbers. Journal of Near Eastern Studies, 52 (1993) nr 4, s. 281-286, https://doi.org/10.1086/373636; D. Young, A Mathematical Approach to Certain Dynastic Spans in the Sumerian King List, ,Journal of Near Eastern Studies” 47 (1988) nr 2, s. 123-129, https://doi.org/10.1086/373263. 
Chociaż Zimri umarł w roku 27 panowania Asy, króla Judy, a Omri objął władzę w roku 31 panowania Asy, króla Judy (1 Krl 16, 15. 18. 21. 23), to nie ma żadnej wzmianki o panowaniu Tibniego, który de facto musiał w tym czasie rządzić. Jednak autor biblijny wyraźnie nie zalicza go do królów.

Inaczej sprawa ma się z Atalią. Autor Ksiąg Królewskich jasno mówi, że Atalia rządziła w kraju (2 Krl 11, 1. 3; 2 Krn 22, 10. 12) ${ }^{12}$. Nie ma żadnego znaczenia ani jej pochodzenie ${ }^{13}$, ani status społeczny ${ }^{14}$. Dobór odpowiedniej panny młodej dla potomka dynastii Dawidowej był zapewne przemyślany ${ }^{15}$. Jednak tutaj liczy się sam fakt zaliczenia jej do rzeczywistych władców, nawet pomimo braku „formuły rządzenia” ${ }^{16}$. Ta poprawka odrzuca koncepcję Hulla, ale pozwala odkryć przesłanie wykazów władców w Księgach Królewskich. Wystarczy zestawić listę królów izraelskich oraz z dynastii Dawidowej obok patriarchów (Rdz 5; 11, 10-26; 1 Krn 1, 1-34), których genealogia jest dziełem teologicznym ${ }^{17}$ oraz obok liter alfabetu hebrajskiego, a odsłoni się pewna

12 N. Na‘aman, Queen Athaliah as a Literay-Historical Figure, „Semitica” 58 (2016), s. 181-205, https:// doi.org/10.2143/SE.58.0.3170087; O. Sergi, Queenship in Judah revisited: Athaliah and the Davidic Dynasty in Historical Perspective, [w:] Tabou et transgressions: Actes du colloque organisé par le Collège de France, Paris, les 11-12 avril 2012, ed. by J.-M. Durand, M. Guichard, T. Römer, FribourgGöttingen 2015 (Orbis Biblicus et Orientalis, 274), s. 99-112, https://doi.org/10.5167/uzh-134494; R. G. Branch, Athaliah, a treacherous queen: A careful analysis of her story in 2 Kings 11 and 2 Chronicles $22: 10-23: 21$, „In die Skriflig” 38 (2004) nr 4, s. 537-560, https://doi.org/10.4102/ids. v38i4.448.

13 Zob. J. Begrich, Atalja, die tochter Omris, „Zeitschrift für die Alttestamentliche Wissenschaft” 53 (1935) nr 1, s. 78-79; H. J. Katzenstein, Who Were the Parents of Athaliah?, „Israel Exploration Journal” 3 (1955), s. 194-197.

14 Zob. S. Ackerman, The Queen Mother and the Cult in Ancient Israel, „Journal of Biblical Literature” 112 (1993) nr 3, s. 385-401, https://doi.org/10.2307/3267740; Z. Ben-Barak, The Status and Right of the Gĕbîrâ, ,JJournal of Biblical Literature” 110 (1991) nr 1, s. 23-34, https://doi.org/10.2307/3267147; N.-E. Andreasen, The Role of the Queen Mother in Israelite Society, „The Catholic Biblical Quarterly” 45 (1983) nr 2, s. 179-194; K. Spanier, The Queen Mother in the Judaean Royal Court: Maacah - A Case Study, [w:] A Feminist Companion to Samuel and Kings, ed. by A. Brenner, Sheffield 1994, s. 186-195; C. Smith, Queenship in Israel? The Cases of Bathsheba, Jezebel and Athaliah, [w:] King and Messiah in Israel and the ancient Near East. Proceedings of the Oxford Old Testament Seminar, ed. by J. Day, Sheffield 1998, s. 142-162 (Journal for the Study of the Old Testament. Supplement series, 270).

15 H. M.Niemann, Choosing Brides for the Crown-Prince. Matrimonial Politics in the Davidic Dynasty, „Vetus Testamentum” 56 (2006) nr 2, s. 225-238, https://doi.org/10.1163/156853306776907467.

16 O formułach rządzenia zob. więcej: S. Bin-Nun, Formulas From Royal Records of Israel and of Judah, ,Vetus Testamentum” 18 (1968) nr 1-4, s. 414-432, https://doi.org/10.1163/156853368X00311; A. Green, Regnal Formulas in the Hebrew and Greek Texts of the Books of Kings, „Journal of Near Eastern Studies” 42 (1983) nr 3, s. 167-180, https://doi.org/10.1086/373017.

17 Por. J. Łach, Problem interpretacji genealogii 1 Krn 1-9, „Ruch Biblijny i Liturgiczny” 38 (1985) nr 2, s. 100-110, https://doi.org/10.21906/rbl.1423; E. Assis, From Adam to Esau and Israel: an 
zaskakująca zbieżność. Z oczywistych względów królowie judzcy będą liczeni od Dawida, a nie od Saula, ponieważ nie Saul, lecz Dawid był założycielem dynastii, która rządziła Judą, obrawszy sobie Jerozolimę za stolicę. Co więcej, to właśnie Dawid zdobył Jerozolimę i uczynił z niej stolicę ${ }^{18}$.

\begin{tabular}{|c|c|c|c|c|}
\hline & & Patriarchowie & Izrael & Dynastia Dawidowa \\
\hline 1 & א & Adam & Saul & Dawid \\
\hline 2 & 1 & Set & Dawid & Salomon \\
\hline 3 & $\lambda$ & Enosz & Salomon & Roboam \\
\hline 4 & $T$ & Kenan & Jeroboam I & Abiasz \\
\hline 5 & ה & Mahalaleel & Nadab & Asa \\
\hline 6 & 1 & Jered & Basza & Jozafat \\
\hline 7 & I & Henoch & Ela & Joram \\
\hline 8 & $n$ & Matuzalem & Zimri & Ochozjasz \\
\hline 9 & 0 & Lamech & Omri & Atalia \\
\hline 10 & 1 & Noe & Achab & Joasz \\
\hline 11 & ך & Sem & Ochozjasz & Amazjasz \\
\hline 12 & 4 & Arfachsad & Joram & Azariasz \\
\hline 13 & no & Szelach & Jehu & Jotam \\
\hline 14 & リ & Heber & Joachaz & Achaz \\
\hline 15 & 0 & Peleg & Joasz & Ezechiasz \\
\hline 16 & ע & Reu & Jeroboam II & Manasses \\
\hline 17 & शๆ & Serug & Zachariasz & Amon \\
\hline 18 & yp & Nachor & Szallum & Jozjasz \\
\hline 19 & ק & Terach & Menachem & Joachaz \\
\hline 20 & 7 & Abraham & Pekachiasz & Jojakim \\
\hline 21 & ש & Izaak & Pekach & Jojakin \\
\hline 22 & $\pi$ & Jakub & Ozeasz & Sedecjasz \\
\hline
\end{tabular}

anti-edomite ideology in 1 Chronicles 1, „Vetus Testamentum” 56 (2006) nr 3, s. 287-302, https:// doi.org/10.1163/156853306778149629.

18 A. Fischer, Von Hebron nach Jerusalem. Eine redaktionsgeschichtliche Studie zur Erzählung von König David in II Sam 1-5, Berlin-New York 2004 (Beihefte zur Zeitschrift für die alttestamentliche Wissenschaft, 335), https://doi.org/10.1515/9783110919561; M. Oeming, Die Eroberung Jerusalems durch David in deuteronomistischer und chronistischer Darstellung (II Sam 5, 6-9 und I Chr 11, 4-8), „Zeitschrift für die Alttestamentliche Wissenschaft” 106 (2009) nr 3, s. 404-420, https://doi.org/10.1515/zatw.1994.106.3.404. 
Lista patriarchów podana jest według tekstu hebrajskiego, nie greckiego, dlatego nie ma na tej liście Kainama (zob. Łk 3, 23-38). Mógł być znany autorom tekstu hebrajskiego ${ }^{19}$, ale pominięcie go dało liczbę 22 patriarchów od Adama do Jakuba ${ }^{20}$. Z tylu liter składał się (i składa się) alfabet hebrajski ${ }^{21}$. Genealogie królów izraelskich i judzkich liczą także po 22 władców. Jest mało prawdopodobne, by był to tylko przypadek. Nowe i głębsze ujęcie kwestii literackich Ksiąg Królewskich rzuca światło na ich teologię ${ }^{22}$. Liczba 22 królów w obu genealogiach mogła być dla autora biblijnego celem nadrzędnym, ważniejszym niż rzeczywista chronologia ${ }^{23}$. Dlatego genealogie królów izraelskich i judzkich najprawdopodobniej nie odzwierciedlają rzeczywistej liczby władców, lecz zostały tak dopasowane, by dawały 22 władców w każdej linii. By uzyskać taki wynik, niektórzy królowie mogli zostać pominięci lub dodani ${ }^{24}$. Poprzez aluzję do całego alfabetu hebrajskiego autor biblijny sugeruje, że epoka królewska zarówno w Izraelu, jak i w Judzie - tak jak epoka patriarchów - jest pełnym i zamkniętym okresem w dziejach Narodu Wybranego ${ }^{25}$.

Prorok Ozeasz uważa ustanowienie Saula za króla jako grzech $(\mathrm{Oz} 8,4$; 9, 15; por. 1 Sm 8, 6-8). Oprócz przeciwników takiej formy rządzenia byli

19 H. R. Jacobus, The Curse of Cainan (Jub. 8. 1-5): Genealogies in Genesis 5 and Genesis 11 and a Mathematical Pattern, „Journal for the Study of the Pseudepigrapha” 18 (2009) nr 3, s. 207-232, https://doi.org/10.1177/0951820709103182.

20 J. Northcote, The Schematic Development of Old Testament Chronography: Towards an Integrated Model, ,Journal for the Study of the Old Testament” 29 (2004) nr 1, s. 31, https://doi. org/10.1177/030908920402900101.

21 J. A. Benner, The Ancient Hebrew Language and Alphabet. Understanding the Ancient Hebrew Language of the Bible Based on the Ancient Hebrew Culture and Thought, College Station 2004, s. 119-120.

22 J. Łach, Jak ujmować w nowy sposób teologię w 1-2 Królów?, „Ruch Biblijny i Liturgiczny” 49 (1996) nr 4, s. 249-255, https://doi.org/10.21906/rbl.842.

23 Por. Zahlen- und Buchstabensysteme im Dienste religiöser Bildung, hrsg. von L. V. Schimmelpfennig, R. G. Kratz, Tübingen 2019 (Studies in Education and Religion in Ancient and Pre-Modern History in the Mediterranean and its Environs, 5), https://doi.org/10.1628/978-3-16-158319-3; T. Hanelt, Znaczenie liczb w Starym Testamencie, „Studia Gnesnensia” 23 (2009), s. 55-64; T. Stanek, Liczby jako aspekt języka religijnego. Przykłady retoryki Tory, „Filozofia Religii” 4 (2008), s. 103-117.

24 Por. np. N. Na'aman, The Royal Dynasties of Judah and Israel, „Zeitschrift für Altorientalische und Biblische Rechtsgeschichte" 22 (2016), s. 59-73; T. Ishida, The Royal Dynasties in Ancient Israel. A Study on the Formation and Development of Royal-Dynastic Ideology, Berlin-New York 1977 (Beihefte zur Zeitschrift für die alttestamentliche Wissenschaft, 142), https://doi. org/10.1515/9783110853766.

25 Por. D. Janzen, Chronicles and the Politics of Davidic Restoration. A Quiet Revolution, LondonOxford-New York-New Delhi-Sydney 2017 (The Library of Hebrew Bible. Old Testament Studies, $655)$. 
także jej zwolennicy (Sdz 8, 22n; 9, 1n; 1 Sm 9, 1-10; 10, 17-24; 12, 1-25). Księgi Samuela zdają się przedstawiać różne poglądy ${ }^{26}$. Po upadku monarchii różnie postrzegano epokę królewską i tę formę rządzenia ${ }^{27}$. Jednak nawet jeśli autor Ksiąg Samuela i Królewskich nie potępia monarchii i sukcesji ${ }^{28}$, to epoka królewska zdaje się być odwróceniem epoki patriarchów. Tak jak za pierwszego człowieka Adama nastąpił upadek ludzkości, tak za ostatniego z królów izraelskich Ozeasza nastąpił upadek Izraela, a za ostatniego z królów judzkich Sedecjasza - upadek Judy. Tak jak Jakub, ostatni z patriarchów, jest najważniejszy dla Izraela, tak i Dawid, pierwszy z dynastii Dawidowej, jest najważniejszy dla domu Dawida. Tak jak trzech ostatnich patriarchów - Abraham, Izaak i Jakub - ma największe znaczenie dla epoki patriarchalnej, tak trzech pierwszych królów - Saul, Dawid i Salomon - ma największe znaczenie dla epoki królewskiej. Genealogie królów Izraela i Judy są zatem wynikiem świadomej kompozycji autora biblijnego przeciwstawiającego epokę królewską epoce patriarchów.

Jeśli trzech pierwszych królów, najważniejszych dla epoki królewskiej, miałoby być odbiciem trzech najważniejszych patriarchów, to mogą oni być tylko legendą ${ }^{29}$. Złote czasy Salomona byłyby zatem także tylko mitem ${ }^{30}$. Nie powinno to dziwić, gdy weźmie się pod uwagę wielowymiarowe odtworzenie postaci biblijnych, którymi przecież są także królowie Izraela i Judy ${ }^{31}$.

W tym świetle łatwo zrozumieć pominięcie przez autora Ksiąg Samuela i Królewskich Abimeleka, który według Księgi Sędziów 9, 22 był pierwszym

26 D. McCarthy, The Inauguration of Monarchy in Israel: A Form-Critical Study of I Samuel 8-12, „Interpretation” 27 (1973) nr 4, s. 401-412, https://doi.org/10.1177/002096437302700403; L. Eslinger, Viewpoints and Point of View in 1 Samuel 8-12, „Journal for the Study of the Old Testament” 8 (1983) nr 26, s. 61-76, https://doi.org/10.1177/030908928300802603.

27 I. Wilson, Kingship and Memory in Ancient Judah, Oxford 2017, https://doi.org/10.1093/acprof:o so/9780190499907.001.0001.

28 J. Blenkinsopp, Another Contribution to the Succession Narrative Debate (2 Samuel 11-20; 1 Kings 1-2), „Journal for the Study of the Old Testament” 38 (2013) nr 1, s. 35-58, https://doi. org/10.1177/0309089213492811. Por. J. Van Seters, A Revival of the Succession Narrative and the Case against It, ,Journal for the Study of the Old Testament” 39 (2014) nr 1, s. 3-14, https://doi. org/10.1177/0309089214551510.

29 Por. B. E. Kelle, The Early Monarchy and the Stories of Saul, David, and Solomon, [w:] S. Niditch, The Wiley Blackwell Companion to Ancient Israel, New York 2015, s. 176-196, https://doi. org/10.1002/9781118774199.ch10.

30 G. J. Wightman, The Myth of Solomon, „Bulletin of the American Schools of Oriental Research” 277-278 (1990), s. 5-22, https://doi.org/10.2307/1357372.

31 H. Witczyk, Wielowymiarowa re-kreacja postaci literackich, „Biblica et Patristica Thoruniensia” 11 (2018) nr 2, s. 177-195, http://dx.doi.org/10.12775/BPTh.2018.009. 
królem Izraela ${ }^{32}$. Jeśli trzech pierwszych królów - Saul, Dawid i Salomon miało być odbiciem trzech ostatnich patriarchów, to zgodnie z tą koncepcją dla Abimeleka - króla przed Saulem, Dawidem i Salomonem - nie było miejsca w genealogiach królów judzkich i izraelskich, nawet jeśli Księga Sędziów miałaby podkreślać znaczenie dynastii Dawidowej ${ }^{33}$.

Łatwiej też zrozumieć kuriozalną przyczynę podziału Zjednoczonego Królestwa na Izrael i Judę (1 Krl 12, 1-20; 2 Krn 10) ${ }^{34}$. Tutaj najbardziej dziwi brak solidarności Judy, który wcale się nie zbuntował, a także sama odpowiedź Roboama, która jest tak niedorzeczna, że nie może być autentycz$\mathrm{na}^{35}$. Archeologia poddaje w wątpliwość istnienie Zjednoczonego Królestwa Izraela $^{36}$. Jeśli rzeczywiście istniało i naprawdę nastąpił bunt dziesięciu pokoleń przeciwko dynastii Dawidowej, nie musiało to nastąpić tuż po śmierci Salomona. Gdyby do buntu owych dziesięciu pokoleń doszło za rządów

32 Por. B. P. Irwin, Not Just Any King: Abimelech, the Northern Monarchy, and the Final Form of Judges, „Journal of Biblical Literature” 131 (2012) nr 3, s. 443-454, https://doi.org/10.2307/23488248.

33 M. Brettler, The Book of Judges: Literature as Politics, „Journal of Biblical Literature” 108 (1989) nr 3, s. 395-418, https://doi.org/10.2307/3267111; por. G. T. K. Wong, Is there a Direct Pro-Judah Polemic in Judges?, „Scandinavian Journal of the Old Testament” 19 (2005) nr 1, s. 84-110, https:// doi.org/10.1080/09018320510032466. Zob. jednak S. Frolov, Fire, Smoke, and Judah in Judges: A Response to Gregory Wong, „Scandinavian Journal of the Old Testament” 21 (2007) nr 1, s. 127138, https://doi.org/10.1080/09018320601171005; zob. także R. H. O'Connell, The Rhetoric of the Book of Judges, Leiden-New York-Köln 1996 (Vetus Testamentum Supplements, 63), https://doi. org/10.1163/9789004275874.

34 Zob. U. Becker, Die Reichsteilung nach I Reg 12, „Zeitschrift für die Alttestamentliche Wissenschaft” 112 (2000) nr 2, s. 210-229, https://doi.org/10.1515/zatw.2000.112.2.210; H. Seebass, Zur Teilung der Herrschaft Salomos nach I Reg 11 29-39, „Zeitschrift für die Alttestamentliche Wissenschaft” 88 (1976) $\mathrm{nr}$ 3, s. 363-376, https://doi.org/10.1515/zatw.1976.88.3.363; E. Lipinski, Le récit de 1 Rois XII 1-19 à la lumière de L'Ancien usage de l'Hébreu et de nouveaux textes de Mari, „Vetus Testamentum” 24 (1974) nr 4, s. 430-437, https://doi.org/10.1163/156853374X00413.

35 Por. T. D. Cudworth, The Division of Israel's Kingdom in Chronicles. A Re-examination of the Usual Suspects, „Biblica” 95 (2014) nr 4, s. 498-523, https://doi.org/10.2143/BIB.95.4.3186128.

36 Z. Thomas, Debating the United Monarchy: Let's See How Far We've Come, „Biblical Theology Bulletin” 46 (2016) nr 2, s. 59-69, https://doi.org/10.1177/0146107916639208; I. Finkelstein, A Great United Monarchy? Archaeological and Historical Perspectives, [w:] One God-One Cult - One Nation, ed. by R. Kratz, H. Spieckermann, Berlin-Boston 2010, s. 1-28, https://doi.org/10.1515/9783110223583.1; zob. także wymianę zdań: I. Finkelstein, The Archaeology of the United Monarchy: an Alternative View, „Levant” 28 (1996) nr 1, s. 177-187, https://doi.org/10.1179/lev.1996.28.1.177; A. Mazar, Iron Age Chronology: A Reply to I. Finkelstein, „Levant” 29 (1997) nr 1, s. 157-167, https://doi.org/10.1179/ lev.1997.29.1.157; I. Finkelstein, Bible Archaeology or Archaeology of Palestine in the Iron Age? A Rejoinder, „Levant” 30 (1998) nr 1, s. 167-174, https://doi.org/10.1179/lev.1998.30.1.167; A. Mazar, J. Camp, Will Tel Rehov Save the United Monarchy?, „Biblical Archaeology Review” 26 (2000) nr 2, s. 38-51. 
Roboama, a nie przed jego wstąpieniem na tron, to Roboam - przynajmniej przez pewien czas - rządziłby wszystkimi pokoleniami, czyli byłby królem nie tylko judzkim, ale także izraelskim. Byłoby zatem nie trzech, lecz czterech królów Zjednoczonego Królestwa i nie byliby odbiciem trzech najważniejszych patriarchów epoki patriarchalnej. Dlatego autor biblijny, niezależnie od historyczności Zjednoczonego Królestwa, umieścił bunt dziesięciu pokoleń zaraz po śmierci Salomona, ale jeszcze przed wstąpieniem Roboama na tron, by tylko trzech królów panowało nad wszystkimi pokoleniami. Sztuczność tegoż zabiegu rzuca się w oczy każdemu uważnemu czytelnikowi Ksiąg Królewskich i Kronik.

Według Rdz 48, 5-20 szczególną rolę wśród pokoleń izraelskich odegrały Manasses i Efraim ${ }^{37}$. Z tego fragmentu wynika także, że z czasem Efraim wziął górę nad Manassesem (Rdz 48, 14). Księga Ozeasza 5, 5 twierdzi wyraźnie, że istniały nie dwa, lecz trzy państwa: Juda, Izrael i Efraim ${ }^{38}$. Księga ta wydaje się być wiarygodnym źródłem historycznym ${ }^{39}$, więc mówienie o dwóch narodach Bożych ${ }^{40}$ jest błędem wynikającym z opierania się na narracji przedstawionej tylko w Księgach Królewskich i Kronik ${ }^{41}$.

Jednak Księgi Królewskie i Kronik przekazują tylko dwie linie królów: izraelskich i judzkich, a zupełnym milczeniem pomijają Efraima. Księgi Kronik powstały później niż Księgi Samuela i Królewskie ${ }^{42}$ i cechują się specyficznym

37 Pismo Święte Starego i Nowego Testamentu w przekładzie z języków oryginalnych, wyd. 5, PoznańWarszawa 2014, przypis do Rdz 48, 5-20.

38 E. R. Thiele, The Mysterious Numbers of the Hebrew Kings. New Revised Edition, Grand Rapids 1994, s. 61, przypis 1.

39 N. Na'aman, The Book of Hosea as a Source for the Last Days of the Kingdom of Israel, „Biblische Zeitschrift” 59 (2015) nr 2, s. 232-256, https://doi.org/10.1163/25890468-059-02-90000005.

40 Np. G. N. Knoppers, Two Nations Under God: The Deuteronomistic History of Solomon and the Dual Monarchies, t. 1: The Reign of Solomon and the Rise of Jeroboam, Leiden 1993 (Harvard Semitic Monographs, 52), https://doi.org/10.1163/9789004369689; G. N. Knoppers, Two Nations Under God: The Deuteronomistic History of Solomon and the Dual Monarchies, t. 2: The Reign of Jeroboam, the Fall of Israel, and the Reign of Josiah, Leiden 1994 (Harvard Semitic Monographs, 53), https://doi. org/10.1163/9789004369696; S. Gelander, From Two Kingdoms To One Nation - Israel and Judah. Studies in Division and Unification, Leiden 2011 (Studia Semitica Neerlandica, 56), https://doi. org/10.1163/ej.9789004203464.i-260.

41 Por. np. K. W. Whitelam, Revealing the History of Ancient Palestine, London 2018 (Changing Perspectives, 8), https://doi.org/10.4324/9781351260404; J. Barr, History and Ideology in the Old Testament: Biblical Studies at the End of a Millennium, Oxford 2000, s. 59-101, https://doi.org/10. 1093/0198269870.001.0001.

42 I. Kalimi, An Ancient Israelite Historian. Studies in the Chronicler, His Time, Place and Writing, Leiden 2005, s. 41-65 (Studia Semitica Neerlandica, 46), https://doi.org/10.1163/9789004358768. 
spojrzeniem na historię ${ }^{43}$. W przeciwieństwie do Ksiąg Królewskich Księgi Kronik nie uznają prawowitości władzy Izraela, uznając ją jako uzurpację i schizmę wobec Judy i Jerozolimy ${ }^{44}$. Ta wyraźna różnica w podejściu do królestwa Izraela sugeruje, że koncepcja dwóch genealogii: królów Judy i Izraela - chociaż w rzeczywistości (przez pewien czas) istniały trzy państwa: Juda, Izrael i Efraim - jest dziełem autora biblijnego Ksiąg Królewskich. Co więcej, dziedzictwo Izraela przetrwało w judejskiej Bibliii ${ }^{45}$. Powstanie Ksiąg Królewskich datuje się na czasy niewoli babilońskiej ${ }^{46}$. Najprostszym wytłumaczeniem takiej koncepcji autora Ksiąg Królewskich jest przyjęcie, że w Babilonii doszło do spotkania babilońskiej diaspory Judejczyków z asyryjską diasporą Izraelitów ${ }^{47}$. Wyjaśniałoby to pominięcie istnienia królestwa Efraima w Księgach Królewskich, a co za tym idzie - także w Księgach Kronik.

Suma lat panowania królów izraelskich od panowania Jehu do upadku Samarii nie zgadza się z faktyczną ilością lat istnienia królestwa Izraela

43 E. Zawiszewski, Księgi Kronik - apologia czy historia, „Ruch Biblijny i Liturgiczny” 21 (1968) nr 4-5, s. 233-237, https://doi.org/10.21906/rbl.3142; H. Witczyk, Historyczno-prorockie tto Dzieła Kronikarskiego, „Ruch Biblijny i Liturgiczny” 49 (1996) nr 1, s. 1-14, https://doi.org/10.21906/ rbl.793.

44 H. G. M. Williamson, Israel in the Books of Chronicles, Cambridge 1977, https://doi.org/10.1017/ CBO9780511557453.

45 D. E. Fleming, The Legacy of Israel in Judah's Bible. History, Politics, and the Reinscribing of Tradition, Cambridge 2012, https://doi.org/10.1017/CBO9781139163033.

46 P. Van Keulen, Manasseh Through the Eyes of the Deuteronomists: The Manasseh Account (2 Kings 21:1-18) and the Final Chapters of the Deuteronomistic History, Leiden 1996, s. 3-52 (Oudtestamentische Studiën. Old Testament Studies, 38); E. Eynikel, The Reform of King Josiah and the Composition of the Deuteronomistic History, Leiden 1995, s. 7-31 (Oudtestamentische Studiën. Old Testament Studies, 33); N. Na'aman, The Contribution of Royal Inscriptions for a Re-Evaluation of the Book of Kings as a Historical Source, ,Journal for the Study of the Old Testament” 24 (1999) nr 82, s. 3-17, https://doi.org/10.1177/030908929902408201; M. Avioz, The Book of Kings in Recent Research (Part I), „Currents in Biblical Research” 4 (2005) nr 1, s. 1155, https://doi.org/10.1177/1476993X05055585; C. Levin, Das synchronistische Exzerpt aus den Annalen der Könige von Israel und Juda, „Vetus Testamentum” 61 (2011) nr 4, s. 616-628, https:// doi.org/10.1163/156853311X560772; J. B. Łach, Powstanie 1-2 Królów w świetle wspótczesnych badań biblijnych, „Resovia Sacra” 13 (2006), s. 5-24.

47 W. Chrostowski, Asyryjska diaspora Izraelitów jako wyzwanie dla biblistyki i asyriologii, „Collectanea Theologica” 86 (2016) nr 3, s. 5-26, http://dx.doi.org/10.21697/ct.2016.86.3.01; W. Chrostowski, Asyryjska diaspora Izraelitów w świetle Księgi Ezechiela - Wojciechowi Pikorowi w odpowiedzi, „The Biblical Annals” 2 (2015) nr 1, s. 75-122, https://doi.org/10.31743/ba; W. Chrostowski, Asyryjska diaspora Izraelitów i inne studia, Warszawa 2003 (Rozprawy i Studia Biblijne, 10); W. Chrostowski, Ogród Eden. Zapoznane świadectwo asyryjskiej diaspory, Warszawa 1996 (Rozprawy i Studia Biblijne, 1). 
w tym okresie. Próbuje się to tłumaczyć współrządzeniem ${ }^{48}$. Królestwo Izraela przestało istnieć półtora wieku wcześniej niż Judy. W linii izraelskiej mogło być zatem mniej królów niż w Judzie. Oznacza to, że niektórzy mogli zostać dodani, by osiągnąć zamierzoną liczbę 22 władców Izraela. Zamiast ich wymyślania autor biblijny mógł wciągnąć do genealogii Izraela niektórych królów Efraima. Przykładem może być tutaj Jeroboam II izraelski, któremu przypisuje się współrządzenie z Joaszem ${ }^{49}$. W rzeczywistości mogli rządzić dwoma różnymi królestwami: Izraelem i Efraimem (zob. Oz 5, 5). Podobnie mogło być z Pekachem w czasie rządów Menachema i Pekachiasza ${ }^{50}$. Włączenie królów Efraima do genealogii izraelskiej spowodowało pozorne współrządzenie. Łatwiej też można zrozumieć problem pokrewieństwa pomiędzy Joramem i Ochozjaszem ${ }^{51}$ - niektórzy sugerują, że Joram izraelski oraz Joram judejski to ta sama osoba ${ }^{52}$. Oznaczałoby to, że Joram został zaliczony do obu rodowodów. Dla autora biblijnego ważniejsza była bowiem liczba 22 władców w genealogii niż brak zgodności pomiędzy sumą lat panowania owych władców a faktyczną liczbą lat istnienia królestwa Izraela w tym czasie.

W tym miejscu warto przypomnieć, że Biblia nie jest podręcznikiem historii ani kroniką narodu Izraela, tak jak traktują ją maksymaliści ${ }^{53}$. Nie jest też fikcją literacką z późniejszych czasów, jak widzą ją minimaliści ${ }^{54}$. Jest nato-

48 Np. E. Thiele, Coregencies and Overlapping Reigns among the Hebrew Kings, ,Journal of Biblical Literature" 93 (1974) nr 2, s. 174-200, https://doi.org/10.2307/3263092.

49 E. R. Thiele, The Mysterious Numbers of the Hebrew Kings. New Revised Edition, Grand Rapids 1994, s. 62-63.

50 Tamże, s. 63.

51 W. Barrick, Another Shaking of Jehoshaphat's Family Tree: Jehoram and Ahaziah Once Again, „Vetus Testamentum” 51 (2001) nr 1, s. 9-25, https://doi.org/10.1163/156853301300102174; D. Etz, The Genealogical Relationships of Jehoram and Ahaziah, and of Ahaz and Hezekiah, Kings of Judah, „Journal for the Study of the Old Testament” 21 (1996) nr 71, s. 39-53, https://doi. org/10.1177/030908929602107104.

52 P. K. McCarter, "Yaw, Son of 'Omri”: A Philological Note on Israelite Chronology, „Bulletin of the American Schools of Oriental Research” 216 (1974), s. 5-7, https://doi.org/10.2307/1356327; J. Strange, Joram, King of Israel and Judah, „Vetus Testamentum” 25 (1975) nr 2, s. 191-201, https://doi.org/10.2307/1517266; E. R. Thiele, An Additional Chronological Note on "Yaw, Son of 'Omri”, „Bulletin of the American Schools of Oriental Research” 222 (1976), s. 19-23, https:// doi.org/10.2307/1356296; M. Weippert, Jau(a) Mar Aumrî - Joram Oder Jehu Von Israel?, „Vetus Testamentum” 28 (1978) nr 1, s. 113-118, https://doi.org/10.1163/156853378X00356.

53 Np. I. W. Provan, V. P. Long, T. Longman, A Biblical History of Israel, Louisville 2003.

54 Np. N. P. Lemche, The Origin of the Israelite State - A Copenhagen Perspective on the Emergence of Critical Historical Studies of Ancient Israel in Recent Times, „Scandinavian Journal of the Old Testament” 12 (1998) nr 1, s. 44-63. https://doi.org/10.1080/09018329808585127; R. B. Coote, Early Israel, „Scandinavian Journal of the Old Testament” 5 (1991) nr 2, s. 35-46, https://doi. 
miast dziełem teologicznym, zawierającym prawdę, która z woli Bożej została utrwalona dla naszego zbawienia ${ }^{55}$, swoistym narzędziem dialogu z Bogiem ${ }^{56}$. Dyskusje uczonych ujawniają niezrozumienie natury Pisma Świętego ${ }^{57}$. Prawda Pisma Świętego nie wynika z jej historycznej dokładności, lecz jest owocem natchnienia Ducha Świętego ${ }^{58}$. Nie wyklucza to wartości historycznej Biblii ${ }^{59}$. Autor Ksiąg Samuela i Królewskich korzystał zapewne z dostępnych mu źródeł znajdujących się być może w Świątyni Jerozolimskiej ${ }^{60}$. Głównym źródłem były Kroniki Królów Izraela i Judy ${ }^{61}$. Być może korzystał także z inskrypcji królewskich ${ }^{62}$. Dlatego jego dzieło zawiera wiele historycznych danych. Nie był jednak współczesnym historykiem, lecz wybitnym teologiem i stąd rozbieżność pomiędzy biblijnym a historycznym Izraelem ${ }^{63}$. Biblijna chronologia królów Izraela i Judy nie jest faktograficzną kalką historii Izraela, lecz teologicznym dziełem autora biblijnego. Jego celem było pokazanie, że

org/10.1080/09018329108584971; K. W. Whitelam, Between History and Literature: The Social Production of Israel's Traditions of Origin, „Scandinavian Journal of the Old Testament” 5 (1991) nr 2, s. 60-74, https://doi.org/10.1080/09018329108584973.

55 M. Majewski, Prawda historyczna Pisma Świętego. Refleksja na kanwie nowego dokumentu Papieskiej Komisji Biblijnej, „Ruch Biblijny i Liturgiczny” 68 (2015) nr 3, s. 237-264, https://doi. org/10.21906/rbl.20.

56 S. Wronka, Pismo Święte narzędziem dialogu z Bogiem, „Ruch Biblijny i Liturgiczny” 69 (2016) nr 4, s. 355-375, https://doi.org/10.21906/rbl.256.

57 Zob. A. Tobolowsky, Israelite and Judahite History in Contemporary Theoretical Approaches, „Currents in Biblical Research” 17 (2018) nr 1, s. 33-58, https://doi.org/10.1177/1476993X18765117; Z. Zevit, Three Debates about Bible and Archaeology, „Biblica” 83 (2002) nr 1, s. 1-27, https://doi. org/10.2143/BIB.83.1.3200291.

58 H. Witczyk, Prawda Pisma Świętego jako owoc natchnienia, „Ruch Biblijny i Liturgiczny” 68 (2015) nr 2, s. 101-124, https://doi.org/10.21906/rbl.13.

59 Papieska Komisja Biblijna, Natchnienie i prawda Pisma Świętego, Kielce 2014.

60 N. Na'aman, The Temple Library of Jerusalem and the Composition of the Book of Kings, [w:] Congress Volume Leiden 2004, ed. A. Lemaire, Leiden-Boston 2006, s. 129-152 (Vetus Testamentum Supplements, 109), https://doi.org/10.1163/9789047408772_008.

61 Zob. M. Haran, The books of the chronicles 'of the kings of Judah' and 'of the kings of Israel': what sort of books were they?, „Vetus Testamentum” 49 (1999) nr 2, s. 156-164, https://doi. org/10.1163/156853399774228948.

62 N. Na'aman, Royal Inscriptions and the Histories of Joash and Ahaz, Kings of Judah, „Vetus Testamentum” 48 (1998) nr 3, s. 333-349, https://doi.org/10.1163/1568533982722414; por. jednak S. Parker, Did the Authors of the Books of Kings Make Use of Royal Inscriptions?, „Vetus Testamentum" 50 (2000) nr 3, s. 357-378, https://doi.org/10.1163/156853300506422.

63 Zob. R. G. Kratz, Historical and Biblical Israel: The History, Tradition, and Archives of Israel and Judah, Oxford 2015, https://doi.org/10.1093/acprof:oso/9780198728771.001.0001; M. Liverani, Israel's History and the History of Israel, London 2007, https://doi.org/10.4324/9781315710433; por. Z. Pawłowski, Historia i teologia w 1 i 2 Księdze Królewskiej, „Teologia i Człowiek” 7-8 (2006), s. 227-238. 
zarówno Juda jak i Izrael są prawdziwym Narodem Wybranym, a epoka królewska - tak jak epoka patriarchów - jest już pełnym i zamkniętym okresem historii.

\section{Abstrakt}

\section{Przyczynek do chronologii królów Izraela i Judy}

Listy królów są wynikiem zamierzonej kompozycji autora biblijnego. Licząc od Saula do Ozeasza dla Izraela oraz od Dawida do Sedecjasza dla dynastii Dawidowej, każda genealogia zawiera 22 władców. Liczba ta nie jest przypadkowa, gdyż są 22 litery w alfabecie hebrajskim, a także 22 patriarchów od Adama do Jakuba. Żeby uzyskać tę liczbę władców w każdym królestwie, niektórzy królowie mogli zostać pominięci lub dodani. Listy królów Izraela i Judy mogą zatem nie odzwierciedlać rzeczywistej chronologii.

Słowa kluczowe: król, Juda, Izrael, chronologia

\section{Abstract}

\section{A Contribution to the Chronology of the Kings of Israel and Judah}

The letters of kings are the result of the Biblical author's intended composition. Beginning with Saul to Hosea for Israel as well as David to Zedekiah for the Davidic dynasty, each genealogy consists of twentytwo rulers. This number is not accidental, as there are 22 letters in the Hebrew alphabet as well as 22 patriarchs from Adam to Jacob. In order to attain this number of rulers in each kingdom, some kings could have been omitted or added. The letters of the kings of Israel and Judah thus do not reflect chronological reality.

Keywords: king, Judah, Israel, chronology

\section{References}

Ackerman, S. (1993). The Queen Mother and the Cult in Ancient Israel. Journal of Biblical Literature, 112(3), 385-401. https://doi.org/10.2307/3267740

Albright, W. F. (1945). The Chronology of the Divided Monarchy of Israel. Bulletin of the American Schools of Oriental Research, 100, 16-22. https://doi.org/10.2307/1355182

Andreasen, N.-E. A. (1983). The Role of the Queen Mother in Israelite Society. The Catholic Biblical Quarterly, 45(2), 179-194.

Assis, E. (2006). From Adam to Esau and Israel: An anti-edomite ideology in 1 Chronicles 1. Vetus Testamentum, 56(3), 287-302. https://doi.org/10.1163/156853306778149629

Auerbach, E. (1952). Die Babylonische Datierung im Pentateuch und das Alter des Priester-Kodex. Vetus Testamentum, 2(1), 334-342. https://doi.org/10.1163/156853352X00426

Auerbach, E. (1959). Der Wechsel Des Jahres-Anfangs in Juda Im Lichte Der Neugefundenen Babylonischen Chronik. Vetus Testamentum, 9(1), 113-121. https://doi.org/10.1163/156853359X00186

Avioz, M. (2016). The Book of Kings in Recent Research (Part I): Currents in Research, 4(1), 11-55. https://doi. org/10.1177/1476993X05055585 
Ball, E. (1977). The Co-Regency of David and Solomon (1 Kings I). Vetus Testamentum, 27(3), 268-279. https:// doi.org/10.1163/156853377X00168

Barnes, W. H. (1991). Studies in the Chronology of the Divided Monarchy of Israel. Scholars Press. https://doi. org/10.1163/9789004369573

Barr, J. (2000). History and Ideology in the Old Testament: Biblical Studies at the End of a Millennium. Oxford University Press. https://doi.org/10.1093/0198269870.001.0001

Barrick, W. B. (2001). Another Shaking of Jehoshaphat's Family Tree: Jehoram and Ahaziah Once Again. Vetus Testamentum, 51(1), 9-25. https://doi.org/10.1163/156853301300102174

Becker, U. (2009). Die Reichsteilung nach I Reg 12. Zeitschrift Für Die Alttestamentliche Wissenschaft, 112(2), 210-229. https://doi.org/10.1515/zatw.2000.112.2.210

Begrich, J. (1935). Atalja, die tochter Omris. Zeitschrift Für Die Alttestamentliche Wissenschaft, 53(1), 78-79.

Ben-Barak, Z. (1991). The Status and Right of the Gĕbîrâ. Journal of Biblical Literature, 110(1), 23-34. https://doi. org/10.2307/3267147

Benner, J. A. (2004). The Ancient Hebrew Language and Alphabet. Understanding the Ancient Hebrew Language of the Bible Based on Ancient Hebrew Culture and Thought. Virtualbookworm.com Publishing.

Bin-Nun, S. R. (1968). Formulas From Royal Records of Israel and of Judah. Vetus Testamentum, 18(1-4), 414-432. https://doi.org/10.1163/156853368X00311

Birdsong, S. L., Frolov, S., \& Sweeney, M. A. (2017). Partners with God theological and critical readings of the Bible in honor of Marvin A. Sweeney. Claremont Press. https://doi.org/10.2307/j.ctvbcd33m

Blenkinsopp, J. (2013). Another Contribution to the Succession Narrative Debate (2 Samuel 11-20; 1 Kings 1-2). Journal for the Study of the Old Testament, 38(1), 35-58. https://doi.org/10.1177/0309089213492811

Branch, R. G. (2004). Athaliah, a treacherous queen: A careful analysis of her story in 2 Kings 11 and 2 Chronicles 22:10-23:21. In Die Skriflig, 38(4), 537-560. https://doi.org/10.4102/ids.v38i4.448

Brettler, M. (1989). The Book of Judges: Literature as Politics. Journal of Biblical Literature, 108(3), 395-418. https:// doi.org/10.2307/3267111

Brzegowy, T. (1998). Chronologia epoki królewskiej w starożytnym Izraelu. Ruch Biblijny i Liturgiczny, 51(4), 261-270. https://doi.org/10.21906/rbl.697

Chrostowski, W. (1996). Ogród Eden. Zapoznane świadectwo asyryjskiej diaspory. Oficyna Wydawnicza Vocatio.

Chrostowski, W. (2003). Asyryjska diaspora Izraelitów i inne studia (2nd ed.). Oficyna Wydawnicza Vocatio.

Chrostowski, W. (2012). Asyryjska diaspora Izraelitów w świetle Księgi Ezechiela - Wojciechowi Pikorowi w odpowiedzi. The Biblical Annals, 2(1), 75-122.

Chrostowski, W. (2016). Asyryjska diaspora Izraelitów jako wyzwanie dla biblistyki i asyriologii. Collectanea Theologica, 86(3), 5-26. https://doi.org/10.21697/ct.2016.86.3.01

Clines, D. J. A. (1974). The Evidence for an Autumnal New Year in Pre-Exilic Israel Reconsidered. Journal of Biblical Literature, 93(1), 22-40. https://doi.org/10.2307/3263863

Clines, David J. A. (1972). Regnal year reckoning in the last years of the Kingdom of Judah. Australian Journal of Biblical Archaeology, 2, 9-34.

Cook, H. J. (1964). Pekah. Vetus Testamentum, 14(2), 121-135. https://doi.org/10.2307/1516376

Coote, R. B. (1991). Early Israel. Scandinavian Journal of the Old Testament, 5(2), 35-46. https://doi.org/10.1080/ 09018329108584971

Cudworth, T. D. (2014). The Division of Israel's Kingdom in Chronicles. A Re-examination of the Usual Suspects. Biblica, 95(4), 498-523. https://doi.org/10.2143/BIB.95.4.3186128

Cundall, A. (1997). Chronologia królów. In D. Alexander, P. Alexander, W. Chrostowski, \& M. Wojciechowski (Eds.), \& T. Mieszkowski (Trans.), Przewodnik po Biblii (4th ed.). Oficyna Wydawnicza Vocatio.

Curtis, E. L. (1895). The Old Testament Reckoning of Regnal Years. Journal of Biblical Literature, 14(1-2), 125-130. https://doi.org/10.2307/3268894 
Eslinger, L. (1983). Viewpoints and Point of View in 1 Samuel 8-12. Journal for the Study of the Old Testament, 8(26), 61-76. https://doi.org/10.1177/030908928300802603

Etz, D. V. (1996). The Genealogical Relationships of Jehoram and Ahaziah, and of Ahaz and Hezekiah, Kings of Judah. Journal for the Study of the Old Testament, 21(71), 39-53. https://doi.org/10.1177/030908929602107104

Eynikel, E. (1995). The Reform of King Josiah and the Composition of the Deuteronomistic History. Brill. https:// brill.com/view/title/127

Finkelstein, I. (1996). The Archaeology of the United Monarchy: An Alternative View. Levant, 28(1), 177-187. https://doi.org/10.1179/lev.1996.28.1.177

Finkelstein, I. (1998). Bible Archaeology or Archaeology of Palestine in the Iron Age? A Rejoinder. Levant, 30(1), 167-174. https://doi.org/10.1179/lev.1998.30.1.167

Finkelstein, I. (2010). A Great United Monarchy? Archaeological and Historical Perspectives. In Reinhard Gregor Kratz (Ed.), One God - One Cult - One Nation. Archaeological and Biblical Perspectives (pp. 1-28). De Gruyter. https://doi.org/10.1515/9783110223583.1

Fischer, A. A. (2004). Von Hebron nach Jerusalem. Eine redaktionsgeschichtliche Studie zur Erzählung von König David in II Sam 1-5. de Gruyter.

Fleming, D. E. (2012). The Legacy of Israel in Judah's Bible: History, Politics, and the Reinscribing of Tradition. Cambridge University Press. https://doi.org/10.1017/CB09781139163033

Frolov, S. (2007). Fire, Smoke, and Judah in Judges: A Response to Gregory Wong. Scandinavian Journal of the Old Testament, 21(1), 127-138. https://doi.org/10.1080/09018320601171005

Galil, G. (1991). The Babylonian Calendar and the Chronology of the Last Kings of Judah. Biblica, 72(3), 367-378.

Galil, G. (1996). The chronology of the kings of Israel and Judah. E. J. Brill.

Gelander, S. (2011). From Two Kingdoms To One Nation-Israel and Judah: Studies in Division and Unification. Brill. https://doi.org/10.1163/ej.9789004203464.i-260

Green, A. R. (1982). The Chronology of the Last Days of Judah: Two Apparent Discrepancies. Journal of Biblical Literature, 101(1), 57-73. https://doi.org/10.2307/3260440

Green, A. R. (1983). Regnal Formulas in the Hebrew and Greek Texts of the Books of Kings. Journal of Near Eastern Studies, 42(3), 167-180. https://doi.org/10.1086/373017

Hanelt, T. (2009). Znaczenie liczb w Starym Testamencie. Studia Gnesnensia, 23, 55-64.

Haran, M. (1999). The books of the chronicles 'of the kings of Judah' and 'of the kings of Israel': What sort of books were they? Vetus Testamentum, 49(2), 156-164. https://doi.org/10.1163/156853399774228948

Hayes, J. H., \& Hooker, P. K. (2007). A New Chronology for the Kings of Israel and Judah and Its Implications for Biblical History and Literature. Wipf and Stock.

Høyrup, J. (1993). "Remarkable Numbers" in Old Babylonian Mathematical Texts: A Note on the Psychology of Numbers. Journal of Near Eastern Studies, 52(4), 281-286. https://doi.org/10.1086/373636

Hull, J. H. (2017). King Lists as a Structuring Principle in the Book of Kings. In S. L. Birdsong \& S. Frolov (Eds.), Partners with God (Vol. 2, pp. 133-146). Claremont Press. https://doi.org/10.2307/j.ctvbcd33m.17

Iriwn, B. P. (2012). Not Just Any King: Abimelech, the Northern Monarchy, and the Final Form of Judges. Journal of Biblical Literature, 131(3), 443-454. https://doi.org/10.2307/23488248

Ishida, T. (1977). The Royal Dynasties in Ancient Israel. A Study on the Formation and Development of Royal-Dynastic Ideology. De Gruyter. https://doi.org/10.1515/9783110853766

Jacobus, H. R. (2009). The Curse of Cainan (Jub. 8. 1-5): Genealogies in Genesis 5 and Genesis 11 and a Mathematical Pattern. Journal for the Study of the Pseudepigrapha, 18(3), 207-232. https://doi.org/10.1177/0951820709103182 Janzen, D. (2017). Chronicles and the politics of Davidic restoration. A quiet revolution. T\&T Clark. Jepsen, A., \& Hanhart, R. (1964). Untersuchungen zur israelitisch-jüdischen Chronologie. A. Töpelmann.

Kalimi, I. (2005). An Ancient Israelite Historian: Studies in the Chronicler, His Time, Place and Writing. Brill. https:// doi.org/10.1163/9789004358768

Katzenstein, H. J. (1955). Who Were the Parents of Athaliah? Israel Exploration Journal, 5(3), 194-197. 
Kelle, B. E. (2015). The Early Monarchy and the Stories of Saul, David, and Solomon. In S. Niditch (Ed.), The Wiley Blackwell Companion to Ancient Israel (pp. 176-196). John Wiley \& Sons, Ltd. https://doi. org/10.1002/9781118774199.ch10

Keulen, P. van. (1996). Manasseh Through the Eyes of the Deuteronomists: The Manasseh Account (2 Kings 21:1-18) and the Final Chapters of the Deuteronomistic History. Brill.

Knoppers, G. N. (1993). Two Nations Under God: The Deuteronomistic History of Solomon and the Dual Monarchies: Vol. 1: The Reign of Solomon and the Rise of Jeroboam. Brill. https://doi.org/10.1163/9789004369689

Knoppers, G. N. (1994). Two Nations Under God: The Deuteronomistic History of Solomon and the Dual Monarchies: Vol. 2: The Reign of Jeroboam, the Fall of Israel, and Reign of Josiah. Brill. https://doi.org/10.1163/9789004369696

Kratz, Reinhard G. (2015). Historical and Biblical Israel: The History, Tradition, and Archives of Israel and Judah. Oxford University Press. https://doi.org/10.1093/acprof:oso/9780198728771.001.0001

Laato, A. (2009). New Viewpoints on the Chronology of the Kings of Judah and Israel. Zeitschrift Für Die Alttestamentliche Wissenschaft, 98(2), 210-221. https://doi.org/10.1515/zatw.1986.98.2.210

Łach, J. B. (2006). Powstanie 1-2 Królów w świetle współczesnych badań biblijnych. Resovia Sacra, 13, 5-24.

Łach, Jan. (1985). Problem interpretacji genealogii 1 Krn 1-9. Ruch Biblijny i Liturgiczny, 38(2), 100-110. https:// doi.org/10.21906/rbl.1423

Łach, Józef. (1996). Jak ujmować w nowy sposób teologię w 1-2 Królów? Ruch Biblijny i Liturgiczny, 49(4), 249-255. https://doi.org/10.21906/rbl.842

Larsson, G. (2006). The Chronology of the Kings of Israel and Judah as a System. Zeitschrift Für Die Alttestamentliche Wissenschaft, 114(2), 224-235. https://doi.org/10.1515/zatw.2002.012

Lemche, N. P. (1998). The origin of the Israelite state-A Copenhagen perspective on the emergence of critical historical studies of ancient Israel in recent times. Scandinavian Journal of the Old Testament, 12(1), 44-63. https://doi.org/10.1080/09018329808585127

Levin, C. (2011). Das synchronistische Exzerpt aus den Annalen der Könige von Israel und Juda. Vetus Testamentum, 61(4), 616-628. https://doi.org/10.1163/156853311X560772

Lipinski, E. (1974). Le récit de 1 Rois XII 1-19 à la lumière de L'Ancien usage de l'Hébreu et de nouveaux textes de Mari. Vetus Testamentum, 24(4), 430-437. https://doi.org/10.1163/156853374X00413

Liverani, M. (2007). Israel's History and the History of Israel. Routledge. https://doi.org/10.4324/9781315710433

Majewski, M. (2015). Prawda historyczna Pisma Świętego. Refleksja na kanwie nowego dokumentu Papieskiej Komisji Biblijnej. Ruch Biblijny i Liturgiczny, 68(3), 237-264. https://doi.org/10.21906/rbl.20

Mazar, A. (1997). Iron Age Chronology: A Reply to I. Finkelstein. Levant, 29(1), 157-167. https://doi.org/10.1179/ lev.1997.29.1.157

Mazar, A., \& Camp, J. (2000). Will Tel Rehov Save the United Monarchy? Biblical Archaeology Review, 26(2), 38-51.

McCarter, P. K. (1974). "Yaw, Son of 'Omri”: A Philological Note on Israelite Chronology. Bulletin of the American Schools of Oriental Research, 216, 5-7. https://doi.org/10.2307/1356327

McCarthy, D. (1973). The Inauguration of Monarchy in Israel: A Form-Critical Study of I Samuel 8-12. Interpretation, 27(4), 401-412. https://doi.org/10.1177/002096437302700403

Miller, J. M. (1967). Another Look at the Chronology of the Early Divided Monarchy. Journal of Biblical Literature, 86(3), 276-288. https://doi.org/10.2307/3263008

Na'aman, N. (1986). Historical and Chronological Notes on the Kingdoms of Israel and Judah in the Eighth Century B.C. Vetus Testamentum, 36(1), 71-92. https://doi.org/10.1163/156853386X00159

Na'aman, N. (1998). Royal Inscriptions and the Histories of Joash and Ahaz, Kings of Judah. Vetus Testamentum, 48(3), 333-349. https://doi.org/10.1163/1568533982722414

Na'aman, N. (2006). The Temple Library of Jerusalem and the Composition of the Book of Kings. In A. Lemaire (Ed.), Congress Volume Leiden 2004 (pp. 129-152). Brill. https://doi.org/10.1163/9789047408772_008

Na'aman, N. (1999). The Contribution of Royal Inscriptions for a Re-Evaluation of the Book of Kings as a Historical Source. Journal for the Study of the Old Testament, 24(82), 3-17. https://doi.org/10.1177/030908929902408201 
Na'aman, N. (2015). The Book of Hosea as a Source for the Last Days of the Kingdom of Israel. Biblische Zeitschrift, 59(2), 232-256. https://doi.org/10.1163/25890468-059-02-90000005

Na’aman, N. (2016a). Queen Athaliah as a Literay-Historical Figure. Semitica, 58, 181-205. https://doi.org/10.2143/ SE.58.0.3170087

Na'aman, N. (2016b). The Royal Dynasties of Judah and Israel. Zeitschrift Für Altorientalische Und Biblische Rechtsgeschichte, 22, 59-73.

Niemann, H. M. (2006). Choosing brides for the crown-prince. Matrimonial politics in the Davidic dynasty. Vetus Testamentum, 56(2), 225-238. https://doi.org/10.1163/156853306776907467

Northcote, J. (2004). The Schematic Development of Old Testament Chronography: Towards an Integrated Model. Journal for the Study of the Old Testament, 29(1), 3-36. https://doi.org/10.1177/030908920402900101

O'Connell, R. H. (1995). The Rhetoric of the Book of Judges. Brill. https://brill.com/view/title/2586

Oeming, M. (2009). Die Eroberung Jerusalems durch David in deuteronomistischer und chronistischer Darstellung (II Sam 5,6-9 und I Chr 11,4-8). Zeitschrift Für Die Alttestamentliche Wissenschaft, 106(3), 404-420. https:// doi.org/10.1515/zatw.1994.106.3.404

Parker, S. (2000). Did the Authors of the Books of Kings Make Use of Royal Inscriptions? Vetus Testamentum, 50(3), 357-378. https://doi.org/10.1163/156853300506422

Pavlovský, V., \& Vogt, E. (1964). Die Jahre der Könige von Juda und Israel. Biblica, 45(3), 321-347.

Pawłowski, Z. (2006). Historia i teologia w 1 i 2 Księdze Królewskiej. Teologia i Człowiek, 7-8, 227-238.

Pismo Święte Starego i Nowego Testamentu w przekładzie z języków oryginalnych (5th ed.). (2014). Pallottinum.

Provan, I. W., Long, V. P., \& Longman, T. (2003). A biblical history of Israel. Westminster John Knox Press.

Redford, D. B. (1965). The Coregency of Tuthmosis III and Amenophis II. The Journal of Egyptian Archaeology, 51, 107-122. https://doi.org/10.2307/3855623

Schimmelpfennig, L. V., \& Kratz, R. G. (Eds.). (2019). Zahlen- und Buchstabensysteme im Dienste religiöser Bildung (1st ed.). Mohr Siebeck. http://doi.org/10.1628/978-3-16-158319-3

Seebass, H. (2009). Zur Teilung der Herrschaft Salomos nach I Reg 11 29-39. Zeitschrift Für Die Alttestamentliche Wissenschaft, 88(3), 363-376. https://doi.org/10.1515/zatw.1976.88.3.363

Segal, J. B. (1957). Intercalation and the Hebrew Calendar. Vetus Testamentum, 7(1), 250-307. https://doi. org/10.1163/156853357X00205

Sergi, O. (2015). Queenship in Judah revisited: Athaliah and the Davidic Dynasty in Historical Perspective. In J.-M. Durand, M. Guichard, \& T. Römer (Eds.), Tabou et transgressions: Actes du colloque organisé par le Collège de France, Paris, les 11-12 avril 2012. Academic Press, Vandenhoeck \& Ruprecht. https://www.zora. uzh.ch/id/eprint/134494/

Seters, J. V. (2014). A Revival of the Succession Narrative and the Case against It. Journal for the Study of the Old Testament. https://doi.org/10.1177/0309089214551510

Smith, C. (1998). Queenship in Israel? The Cases of Bathsheba, Jezebel and Athaliah. In J. Day (Ed.), King and Messiah in Israel and the ancient Near East. Proceedings of the Oxford Old Testament Seminar (pp. 142-162). Sheffield Academic Press.

Spanier, K. (1994). The Queen Mother in the Judaean Royal Court: Maacah-A Case Study. In A. Brenner-Idan (Ed.), A Feminist Companion to Samuel and Kings (pp. 186-195). Sheffield Academic Press.

Stanek, T. (2008). Liczby jako aspekt języka religijnego. Przykłady retoryki Tory. Filozofia Religii, 4, 103-117.

Strange, J. (1975). Joram, King of Israel and Judah. Vetus Testamentum, 25(2), 191-201. https://doi.org/10.2307/ 1517266

Talmon, S. (1958). Divergences in Calendar-Reckoning in Ephraim and Judah. Vetus Testamentum, 8(1), 48-74. https://doi.org/10.1163/156853358X00042

Tetley, M. C. (2005). The reconstructed chronology of the Divided Kingdom. Eisenbrauns.

Thiele, E. R. (1944). The Chronology of the Kings of Judah and Israel. Journal of Near Eastern Studies, 3(3), 137-186. https://doi.org/10.1086/370716 
Thiele, E. R. (1954). A Comparison of the Chronological Data of Israel and Judah. Vetus Testamentum, 4(1), 185-195. https://doi.org/10.1163/156853354X00172

Thiele, E. R. (1966). Pekah To Hezekiah. Vetus Testamentum, 16(1), 83-107. https://doi.org/10.1163/156853366X00458

Thiele, E. R. (1974). Coregencies and Overlapping Reigns among the Hebrew Kings. Journal of Biblical Literature, 93(2), 174-200. https://doi.org/10.2307/3263092

Thiele, E. R. (1976). An Additional Chronological Note on "Yaw, Son of 'Omri." Bulletin of the American Schools of Oriental Research, 222, 19-23. https://doi.org/10.2307/1356296

Thiele, E. R. (1994). The mysterious numbers of the Hebrew kings. Kregel.

Thomas, Z. (2016). Debating the United Monarchy: Let’s See How Far We've Come. Biblical Theology Bulletin, 46(2), 59-69. https://doi.org/10.1177/0146107916639208

Tobolowsky, A. (2018). Israelite and Judahite History in Contemporary Theoretical Approaches: Currents in Biblical Research, 17(1), 33-58. https://doi.org/10.1177/1476993X18765117

Weippert, M. (1978). Jau(a) Mār Huumrî—Joram Oder Jehu Von Israel? Vetus Testamentum, 28(1), 113-118. https:// doi.org/10.1163/156853378X00356

Whitelam, K. W. (1991). Between history and literature: The social production of Israel's traditions of origin. Scandinavian Journal of the Old Testament, 5(2), 60-74. https://doi.org/10.1080/09018329108584973

Whitelam, K. W. (2018). Revealing the history of ancient Palestine (E. Pfoh, Ed.). Routledge. https://doi. org/10.4324/9781351260404

Wifall, W. R. (2009). The Chronology of the Divided Monarchy of Israel. Zeitschrift Für Die Alttestamentliche Wissenschaft, 80(3), 319-337. https://doi.org/10.1515/zatw.1968.80.3.319

Wightman, G. J. (1990). The Myth of Solomon. Bulletin of the American Schools of Oriental Research, 277-278, 5-22. https://doi.org/10.2307/1357372

Williamson, H. G. M. (1977). Israel in the Books of Chronicles. Cambridge University Press. https://doi.org/10.1017/ CB09780511557453

Wilson, I. (2017). Kingship and Memory in Ancient Judah. Oxford University Press. https://doi.org/10.1093/acprof :oso/9780190499907.001.0001

Witczyk, H. (1996). Historyczno-prorockie tło Dzieła Kronikarskiego. Ruch Biblijny i Liturgiczny, 49(1), 1-14. https://doi.org/10.21906/rbl.793

Witczyk, H. (Ed.). (2014). Natchnienie i prawda Pisma Świętego. Stowo, które od Boga pochodzi i mówi o Bogu, aby zbawić świat. Instytut Teologii Biblijnej Verbum.

Witczyk, H. (2015). Prawda Pisma Świętego jako owoc natchnienia. Ruch Biblijny i Liturgiczny, 68(2), 101-124. https://doi.org/10.21906/rbl.13

Witczyk, H. (2018). Wielowymiarowa re-kreacja postaci literackich. Biblica et Patristica Thoruniensia, 11(2), 177-195. https://doi.org/10.12775/BPTh.2018.009

Wong, G. T. K. (2005). Is there a Direct Pro-Judah Polemic in Judges? Scandinavian Journal of the Old Testament, 19(1), 84-110. https://doi.org/10.1080/09018320510032466

Wronka, S. (2016). Pismo Święte narzędziem dialogu z Bogiem. Ruch Biblijny i Liturgiczny, 69(4), 355-376. https:// doi.org/10.21906/rbl.256

Young, D. W. (1988). A Mathematical Approach to Certain Dynastic Spans in the Sumerian King List. Journal of Near Eastern Studies, 47(2), 123-129. https://doi.org/10.1086/373263

Zawiszewski, E. (1968). Księgi Kronik - apologia czy historia. Ruch Biblijny i Liturgiczny, 21(4-5), 233-237. https:// doi.org/10.21906/rbl.3142

Zevit, Z. (2002). Three Debates about Bible and Archaeology. Biblica, 83(1), 1-27. https://doi.org/10.2143/ BIB.83.1.3200291 